\title{
The Influence of Students' Goal Orientation Toward Their Speaking Ability at Junior High School at Pekanbaru City
}

\author{
Candra Kirana $^{1)}$ and Evis Ritawani ${ }^{2}$ \\ ${ }^{1}$ Akademi Kebidanan Helvetia Pekanbaru \\ E-mail: Ckirana17@gmail.com \\ ${ }^{2}$ Akademi Kebidanan Helvetia Pekanbaru \\ E-mail: evisritawani@gmail.com
}

\begin{abstract}
The main objective of this study was to find out the Correlations of Students' Goal Orientation toward their Speaking Ability in in Junior High Schools in Pekanbaru City. This study was correlationals study which students Goal Orientation and students' speaking Ability. The participants in this study were second year students in vocational in Junior High Schools in Pekanbaru City. The instrument used in order to obtain the data were questionnaires for assessing students' Goal Orientation. Then, in assessing students' speaking ability, the test was conducted. After analyzing the data by using Statistical Package of Social Science (SPSS) 20 version, it was obtain that students' Goal Orientation was in medium level $(\mathrm{M}=85$, SD 10.34441). Moreover, students' speaking ability was in low level (M: 56.50; Std. Deviation 0.56325). After analyzing data, the finding showed that there was significant using statistical analysis of correlation, it shows the relationship between students' Goal Orientation and their speaking ability $(\mathrm{r}=0.925, \mathrm{p}=0.00)$. Futuremore, this study suggested that students' goal orientation of Speaking English should be enhanced and in order to assist students managed to thier academic succsess.
\end{abstract}

Keywords: Goal Orientation, Speaking Ability and Junior High Schools in Pekanbaru City 


\section{INTRODUCTION}

This study is integrated with affective domains from an educational psychological perspective. The main point of affective fundamental factor based on the phenomena and problem that happening naturally. According (Elliot, 2005) states that Affective factor is always something crucial problem happen English foreign language. It refers to students' feels, interest, mood, belief, intention, motivation, goal orientation, foreign language anxiety and etc.

Based on the statement above, there are many areas studies about affective domain. Therefore, the study focuses on the area of goal orientation and Speaking ability. The term of Goal Orientation has been described as a complicated construct and sometimes a multifaceted concept (Okada et al:2005). According to Otis (2005), there are many terms of Goal Orientation such as: achievement motivation, achievement goal, mastery oriented, task oriented, self-goal oriented, and etc.

When it comes to definition, perhaps, the most frequently cited definition of Goal Orientation is taken from Van Yperen (2003) who define Orientation is framework to study the role of motivation in academic context. It has referred to whether individuals primarily strive to enhance their knowledge, skills, and competence, referred to as a learning orientation. Addition, he is also define that goal orientation is activation mind-set or schema of achievement situations. In addition, he states the activation of those schemas of achievement is supposed to guide thoughts, feeling, and behavior in correspondence in the goals.

Moreover, this study was to combine the concept goal orientation perspective areas. Some of researcher is great deal to mix the concept of perspective of goal orientation widely. According to Elliot and Song (1997) goal orientation is the human need as dream. They provide goal orientation is not just a dream to be success, but it is include define individuals' belief that reflection of mindset and feeling to be focus. In addition, they state that goal orientation is a purpose to build of trust in personality. In brief, they state that if someone trust in his/herself, it would motivate to the individuals' be passion. The also state that the passion is a powerful to support individual to extravagant fondness, enthusiasm, or desire for work hard. Work hard is effort to using a lot of time and energy to working maximally to do usefull activities and increase a feeling that never surrender to achieve the target knowledge, skill and experiences.

Some of research has found by Howirz (1987), Dweck and Elliot (1995) et al, the highest of goal orientation influence highest of students' achievement. The others researchers have found by Schunk and Meece et al (2008: 142), they have found that student has the goal orientation to realize their dreams tend to include belief in useful activities. In addition, that they stated goal orientation provides students' strong belief that is supporting their expectation and attention to the process, training to conduct information, aware effort, and be defensives.

In other side, it is great deal for student as set roles interpretation to academic success. An example, students is known English became international language used in daily communication and also supporting career. When the student has goal orientation, it is provided student become one of primary aim should be mastered. It was useful to provide the reason why student engage in achievement behavior where focus on developing competences.

As we know, a numbers of country included Indonesia that speaking competence became productive skills; it is the foundation in 
developing a good communication skill. It is one of the key in academic success. Based on Badan Standard Nasional Pendidikan (BSNP), they have goal orientation in KTSP Curriculum (2008). They stated students able to speak accuracy, fluency, and good pronunciation, politeness, acceptable in formal and informal situation, to expressing idea, feeling, and needs. In reality, the most of students' speaking ability can't achieve the target of curriculum. The teacher has given the best strategy in teaching and learning process, but the most of students were still low motivation, interest, and self confident in learning.

Based on explanation above, Goal Orientation theorists also have engaged in attempt to determine the types of goals that are most productive for students and what types of goals result in the cognitive strategies, affective responses, and behaviors which lead to student success. On the other hand, Goal Orientation theories examine students' beliefs about their successes; it also examines the reasons why students engage in their academic work. Students are able to solve the problem, and the problem as challenge. It conveys their intrinsic and extrinsic motivation to increase ability, intention, aware effort, and how students set cognitive and affective side to success in academic.

\section{METHOD}

The design used in this research was a correlation study. As stated by Fraenkel and Wallen (2008), correlation study is sometimes called by associational research. It is the relationship among two or more variables.

Based on explanation above, it is clear that a correlation research design is appropriate because it correlates one variable to the others. It can be stated that this study provides a positive correlation; it means that high score is related to high score and low score is related to low score.

ELT- Lectura: Jurnal Pendidikan, Vol 6, No 1, February 2019
Conversely, this study provides a positive correlation, it means that high score is related to low score and low score is related to high score. In addition, this study also used quantitative data in educational psychology which Goal Orientation Language frameworks areas.

\section{FINDINGS AND DISCUSSION}

The Influence of Students' Goal Orientation and Foreign Language Anxiety on their Speaking Ability was the result in this research. The total number of respondents was 92 second year students from three Junior high schools in Pekanbaru City. To measure two variables, two kinds of questionnaires were used. First, Goal Orientation Questionnaire was adoptedfrom Elliot and McGregor (2000), which consisted of 25 statements with five options of LikertScale; Strongly Agree (5), Agree (4), Undecided (3), Disagree (2) and Strongly Disagree (1). Second, the data of speaking ability were taken from students' speaking assessment score adopted from Artur Huges and Brown (2001:384). The data were analyzed by using descriptive and inferential statistic. All the data analysis included frequency distribution, percentages, mean scores, and standard deviation of the variables.

Table 1.

\section{Descriptive Statistics of Students' Goal Orientation at Junior High Schools in Pekanbaru City}

\begin{tabular}{lcc}
\hline \multicolumn{1}{c}{ Classification } & F & \% \\
\hline High & 20 & 21.7 \\
Medium & 71 & 77.2 \\
Low & 1 & 1,1 \\
\hline
\end{tabular}

N:92 Mean: 85 ; Std. Deviation: 10.32441 
Table 1 shows that the highest frequency of students' goal orientation is in medium level with ( $\mathrm{F}=71$ or $77.2 \%)$. Then, it is followed by high level with $(\mathrm{F}=20$ or $21.7 \%)$, and low level is ( $\mathrm{F}$ $=1$ or $1.1 \%)$. Sincethe mean score of students' goal orientation is 85 , it is categorized into medium level. Thus, the students' goal orientation at Junior high schools in Pekanbaru City is in moderate level.

The classification was used to determine how the level of students' Foreign Language Anxiety is. The result of frequency distribution of students' foreign language anxietyis presented in table 2 .

The classification was used todetermine how the level of students' Speaking Ability is. The result of frequency distribution of students' speaking ability is presented in the table 2 .

Table 2.

Descriptive Statistics of Students' Speaking Ability at Junior High Schools in Pekanbaru City

\begin{tabular}{cccc}
\hline No & Description & Frequency & Percentage \\
\hline 5 & Excellent & - & \\
4 & Good & 1 & 1,1 \\
3 & Enough & 33 & 35,9 \\
2 & Low & 55 & 59,8 \\
1 & Fail & 3 & 3,3 \\
\hline & Total & N 92 & 100 \\
\hline
\end{tabular}

Mean: 56.50; Std. Deviation 0.56325

Table 2 shows that the highest percentage of students' speaking ability is in low level with $(\mathrm{F}=$ 55 or $59.8 \%$ ), the second is in enough level with
$(\mathrm{F}=33$ or $35.9 \%)$, the third is in fail level with ( $\mathrm{F}$ $=3$ or $3.3 \%)$, and the last is in good level with ( $\mathrm{F}$ $=1,1,1 \%)$. Since the result ofmean score is 56.50 , it is categories into low level. So, it can be concluded that students' speaking ability is in low level. It means that most of them have low ability in speaking ability in Pekanbaru City.

\subsection{The Correlation between Students' Goal Orientation and Their Speaking Ability.}

To examine the correlation between students' Goal Orientation and their speaking ability, Pearson Product moment was used. The following table presents about the correlation result between students' Goal Orientation and their speaking ability in table 3 .

Table 3.

The Correlation between Goal Orientation and Their Speaking Ability at Junior High Schools in Pekanbaru City

Speaking Ability

\begin{tabular}{ccc}
\cline { 2 - 3 } & $\mathrm{R}$ & $\mathrm{P}$ \\
\hline Goal Orientation & .925 & .00
\end{tabular}

Based on the table 3, by using statistical analysis of correlation, it shows the relationship between students' Goal Orientation and their speaking ability $(r=0.925, p=0.00)$. Because the significant probabilities of this result is lower than 0.05 , it can be inferred that there is a significant correlation between students' Goal Orientation and their speaking ability. 


\section{CONCLUSION}

The findings of this research revealed that; there was a significant correlation between of Goal Orientation toward students' Speaking Ability. These conclusions had some implications in the field of teaching. First of all, being a teacher was not only to teach students the material of a subject a researcher, facilitator and problem solver in teaching and learning process. In other hand, the teacher was not only give attention to teach cognitive side but also pay attention in affective side. In line to this, affective side has been very important for the students in learning process, it has about students' mentality inside such as feeling, interest, mood, motivation, goal orientation, anxiety and emotion (Oxford, 1999).

In defining the context, many aspects should be considered by the teachers, especially in students' speaking ability. The most of students was found low ability in speaking ability, it was caused low of their goal orientation in Learning English, speaking ability did not as primary goal, and they though pass exam although they able or not speaking English, they though English as foreign language, it did not use in daily communication. The other hand, the student goal oriented in speaking English is low because the most examination only focus on multiple choices that determine the students' low of interest to speaking English. So, the teacher should be change students' goal orientation in speaking English, master of speaking English primary goal of student, because the nature of language is communicates. Speaking English has been important to their skills, because English is an international language. Even technology and working world use English. It is believed that the students want to be the winner in working world competition that is getting tight day by day. One of the conditions that the students must require is having ability to speak English fluently. This skill will be their plus point in facing the working world. From now on, the students have to try hard to overcome their difficulties to speak English fluently.

\section{REFERENCES}

Ames, C. (1992). Classrooms: Goals, structures, and student motivation. Journal of Educational Psychology, 84 (3), 261271.

Ary, D., Jacobs, L. C., Razavieh, A., \& Sorensen, C. (2006). Introduction to research in education (7th Ed). Thomson Wadsworth, Thomson Higher Education anxiety research suggest? Modern Language Journal, 75,426436.

Brdar, I., Rijavec, M., \& Loncaric, D. (2006). Goal orientations, coping with school failure and school achievement. European Journal of Psychology of Education, 21 (1), 53-70.

Byme, S. R. (2011). Motivation: Goal orientation among middle school students. Thesis. College of Liberal Studies, Program Department of Psychology, School Psychology

Chan, K. W., Leung, M. T., \& Lai, P. Y. (2004). Goal orientations, study strategies and achievement of Hong Kong teacher education student. Hong Kong Institute of Education. Paper presented at the AARE2004 Conference held at Melbourne, Australia, 28th Nov.-2nd Dec, 1-15.

Cocks, R. J. \& Watt, H. M. G. (2004). Relationships among perceived competence, intrinsic value and mastery goal orientation in English and 
Maths. The Australian Educational Researcher, 31(2), 81-112.

Deemer, S. A. (2004). Using achievement goal theory to translate psychological principles into practice in the secondary classroom. American Secondary Education, 32 (3), 4-15.

DeShon, R. P., \& Gillespie, J. Z. (2005). A motivated action theory account of goal orientation Journal of Applied Psychology, 90 (6), 1096-1127.

Dweck, C. S. \& Leggett, E. L. (1988). A socialcognitive approach to motivation and personality. Psychological Review, 95 (2), 256-273.

Dweck, C. S. (1986). Motivational processes affecting learning. American Psychologist, 41 (10), 1040-1048.

Eccles, J. S., Wigfield, A., Harold, R. D., \& Blumenfeld, P. (1993). Age and gender differences in children's self- and task perceptions during elementary school. Child Development, 64, 830-847.

Elliot, A. (2006). The hierarchical model of approach-avoidance motivation. Motivation and Emotion, 30 (2), 111116.

Elliot, A. J. (2005). A conceptual history of the achievement goal construct. In A. J. Elliot \& C. S. Dweck (Eds.), Handbook of competence and motivation (pp.5272). New York: Guilford Press.

Elliot, A. J., \& McGregor, H. A. (2001). A $2 \times 2$ achievement goal framework. Journal of Personality and Social Psychology, 80 (3), 501-519.

Elliott, E. S., \& Dweck, C. S. (1988). Goals: An approach to motivation and achievement. Journal of Personality and Social Psychology, 54, 5-12. guide to creating a low-anxiety classroom atmosphere (pp. 24-45). Toronto: McGraw-Hill.

Hinkley, J. W., McInerney, D. M., \& Marsh, H. W. (2001). The multi- faceted structure of school achievement motivation: A case for social goals. Paper presented at the Annual Meeting of the American Educational Research Association, Seattle, USA.

Kenny-Benson, G. A., Pomerantz, E. M., Ryan, A. M., \& Patrick, H. (2006). Sex differences in math performance: The role of children's approach to schoolwork. Developmental Psychology, 42, 11-26.

Kim, S. Y. (1998). Affective experiences of Korean college students in different instructional contexts: Anxiety and motivation in reading and conversation courses. Unpublished doctoral dissertation, The University of Texas, Austin.

Kitano, K. (2001). Anxiety in the college Japanese language classroom. The Modern Language Journal, 85(4), 549566.

Kwok-wai, CH., Po-yin, L., Man-tak, L. \& Phillip, M. (2002). Hong Kong preservice teachers' achievement goal orientations - are they related to their gender and electives? Hong Kong Teachers' Centre Journal, 1, 20-31.

MacIntyre, P. D. (1999). Language anxiety: A review of the research for language teachers. In

McLellan, R. (2006). The impact of motivational "world-view" on engagement in a cognitive acceleration programme. International Journal of Science Education, 28 (7), 781-819. 
Meece, J. L., \& Holt, K. (1993). A pattern analysis of students' achievement goals. Journal of Educationa1 Psychology. 85 (4), 582-590.

Meece, J. L., Anderman, E. M., \& Anderman, L. H. (2006a). Classroom goal structure, student motivation and academic achievement. Annual Review of Psychology, 57, 487-503.

Meece, J. L., Glienke, B. B., \& Burg, S. (2006b). Gender and motivation. Journal of School Psychology, 44, 351-373.

Middleton, M. J. \& Midgley, C. (1997). Avoiding the demonstration of lack of ability: An underexplored aspect of goal theory. Journal of Educational Psychology, 89(4), 710-718.

Midgley, C., Kaplan, A., Middleton, M., Maehr, M. L., Urdan, T., Anderman, L. H., Anderman, E. \& Roeser, R. (1998). The development and validation of scales assessing students' achievement goal orientations. Contemporary Educational Psychology, 23, 113-131.

Nicholls, J. G. (1975). Causal attributions and other achievement-related cognitions: Effects of task outcome, attainment value, and sex. Journal of Personality and Social Psychology, 31, 379-389.

Nicholls, J. G. (1984). Achievement motivation: Conceptions of ability, subjective experience, task choice, and performance. Psychological Review, 91, 328-346.

Patrick, H., Ryan, A. M., \& Pintrich, P. R. (1999). The differential impact of extrinsic and mastery goal orientations on males' and females' self-regulated learning. Learning and Individual Differences, 11, 153-171.
Pintrich, P. (2000). An achievement goal theory perspective on issues in motivation terminology, theory, and research. Contemporary Educational Psychology, 25, 92-104.

Pintrich, P. R., \& Schunk, D. H. (2002). Motivation in education: theory, research, and applications (2nd ed.). Upper Saddle River, New Jersey: Prentice-Hall.

Rabideau, S. T. (n.d). Effects of achievement motivation on behavior. Rochester Institute of Technology, 1-13. Retrieved Dec. $\quad 18, \quad 2010$ fromhttp://www.personalityresearch.org/ papers/rabideau.

Rijavec M., \& Brdar I. (2002). Coping with school failure and self-regulated learning. European Journal of Psychology of Education, 17(2), 177194.

Ryan, A. M., Hicks, L., \& Midgley, C. (1997). Social goals, academic goals, and avoiding seeking help in the classroom. Journal of Early Adolescence, 17, 152171.

Sarason, C. A., Rahm, K. B., Beigbeder, S. A., \& Metts, S. (2005). The link between the pursuit of intimacy goals and satisfaction in close same-sex friendships: An examination of the underlying processes. Journal of Social and Personal Relationships,22(1), 75-98.

Thorkildsen, T. A., \& Nicholls, J. G. (1998). Fifth-graders' achievement orientations and beliefs: Individual and classroom differences. Journal of Educational Psychology, 90, 179-201.

Van Yperen, M., Simons, J., Lens, W., Soenens, B., Matos, L., \& Lacante, M. (2004). Less is sometimes more: Goal-content 
matters. Journal of

EducationalPsychology, 96, 755-764.

Was, C. (2006). Academic achievement goal orientation: Taking another look. Electronic Journal of Research in Educational Psychology, 4(3), No.10, 529-550.

Young, D. J. (1991). Creating a low-anxiety classroom environment: What does language.

Zhang, L. J. (2001). Exploring variability in language anxiety: Two groups of PRC students learning ESL in Singapore. RELC Journal, 32(1), 73-94. http://dx.doi.org/10.1177/003368820103 200105 